\title{
CONTENT MODIFICATION OF TRADITIONAL UKRAINIAN CHORUSES DURING THE SOVIET IDEOLOGICAL PRESSING (1917-1991) AND THE PRESENT
}

\section{Ovcharenko S. V.}

\section{INTRODUCTION}

At all times, traditional performance, along with language, has existed as an important bulwark for the preservation of the identity of Ukrainians, having extraordinary importance in the formation of the national idea. Historically, folklore has been discriminated against by the Soviet authorities in the context of Russification, at a time when everything Ukrainian was being destroyed, because it is one of the indicators of the nation.

In the Soviet period, the priority was to create a single artificial system of culture, which functioned through political forces in order to spread state ideology. As a result of these actions by the state apparatus, we have a fusion of the richness of regional traditions (local varieties of folk building, clothing, singing, instrumental traditions).

The traditional culture of any nation by its nature has the ability to change, to combine with the elements of the culture of neighboring nations over a period of time (centuries). Ukrainian culture is no exception, despite the difficult historical periods when the lands of the Ukrainian state were scattered, it thanks to the national elite, existed and developed in ontogenesis.

The concretization of the facts of influence on the traditional Ukrainian musical culture in the Soviet historical period is actualized, to reveal methods of the transformation processes directed on semantic modification of melodic forms of traditional Ukrainian melodies. Analyze and reveal changes in folk art. Identify the facts of influence on the authentic song tradition during the Soviet period (1917-1991), which led to the modification of symbiotic local regional melodies (on the example of song material of Dnieper Ukraine and Transcarpathia). Analyze the facts of political influence on the selection of song repertoire of professional and amateur choirs.

In our time, the question of "unveiled" study of the Ukrainian people creativity, its intangible and tangible assets, which is due to the search for new conceptual foundations for the revival and development of the national folk song tradition. Today's realities encourage scholars (E. Yefremova, 
I. Klymenko, M. Skazheniuk, etc.) to focus on local lore research, study the features of regional song and ethnographic heritage, analyze the impact of socio-economic and political processes on traditional Ukrainian songs in various historical periods.

The problem of research of Ukrainian traditional performance of the twentieth century (1917-1991) is to identify the factors of external "reform", as well as the assimilative processes that it underwent during the Soviet historical period. All the processes of modification that took place in these time limits in traditional culture, primarily in folk song performance, were aimed solely at the deconsolidation of the nation, through the prism of culturological transformations.

The issue of transformation of traditional performance has become interesting among domestic ethnomusicologists of the last two centuries. The result of their titanic research work is the works: "Rhythmic parallels in the songs of the Slavic peoples" (K. Kvitka, 1923), "Ukrainian folk songs at the turn of the XVII - XVIII centuries" (F. Kolessa, 1928), "Ukrainian folk music" (A. Ivanitskyi, 1990), "Folklore and modernity" (S. Hrytsa, 1996), "Folklore in space and time" (S. Hrytsa, 2000), "Transmission of folk tradition" (S. Gritsa, 2002).

S. Hrytsa in the work "Folklore and modernity" notes that: "The problem can be solved provided awareness of the need to preserve the integrity of ethnic culture with differentiation in its historical and geographical layers and overcoming the inertia of the past-political strife that has eroded for centuries the Ukrainian people, pouring water on the mill of the neighboring international environment"1.

The modern vision of the issue is described in the articles: "Publication of song folklore of 1919-1921 in the special fund of the Book Chamber of Ukraine: bibliological aspect" (A. Hailo, 2020), "The problem of embodying the traditions of Ukrainian national melody in the second half of the twentieth century" (N. Broiako, V. Dorofieieva, 2017).

\section{Modification of traditional Ukrainian musical culture in the Soviet historical period}

Historical processes that took place in the late nineteenth - the early twentieth century, namely: urbanization, industrialization, elimination of illiteracy in the 20s-30s of the twentieth century, can be considered a prerequisite for modification in the traditional song performance of Ukrainians. The process of Russification, which has been going on since the tsarist system, had a special influence on traditional culture, but its most

\footnotetext{
${ }^{1}$ Грица С. Фольклор і сучасність. Украӥнська художня культура : навчальний посібник. Київ, 1996. С. 300-314.
} 
active phase is observed during the period of Soviet rule in modern Ukraine ${ }^{2}$. The main purpose of this process is the so-called "reform" of all spheres of life of Ukrainians, including folk art in its various manifestations (traditional musical performance, decorative and applied, fine arts, architecture, etc.).

The chronological period of 1917-1991, according to modern historians and scientists, was a period of zombie masses. Examining the existence of Ukrainian traditional holidays of the family cycle in the conditions of the onset of Soviet ideology, O. Braichenko notes that at the time of the formation of Bolshevik rule in Ukraine no "ideal" society was formed with a customary system of customs, which prevented the rapid spread of state ideology ${ }^{3}$. With the advent of Soviet power, along with atheism, begins the transformation of the calendar and the family-ritual system as one that functioned throughout the existence of the people. Since then, there has been a tendency to actively use music and culture in general as a tool for instilling a certain ideology, by various means.

From this point of view, we will consider the factors of influence that led to the semantic modification of traditional Ukrainian melodies. The most acute problem was the subtexting of newly created plots to the traditional melody.

Traditional melodies, which have always ensured the functioning of the ritual system, have been subpoenaed to new plots that correspond to the ideological and aesthetic state content and perform an ideological function. As a result, low-quality samples of "collective creativity" were formed, which, however, were not rooted in musical performance. Semantic modification, by experiment, affected all song genres of folk art. Works created by historical events of the previous day or phenomena in everyday life were connected in content with the events of later times, undergoing changes in texts or melodies, i.e., subject to modification of semantic and melodic forms ${ }^{4}$.

First of all, historical songs that were widely known were modified, later local musical samples, little known to the general public, were changed. They were the most numerous units of musical folklore that met purely aesthetic needs and also performed a ritual function in a certain traditional locus. These are mainly songs of calendar-ritual and family-ritual cycles. Usually, the heroes of the plots in the samples of collective folk art were

2 Потебня А. Объяснение малорусских и сродных народных песен. Варшава, 1883. T. 1. С. 103.

Брайченко О. Побутування українських традиційних свят родинного циклу в умовах наступу радянської ідеології 70-80-х років XX століття. Народна творчість та етнологія. 2014. № 4. С. 115-127.

4 Ященко Л. Радянська пісня : монографія / за ред. А. Кінька. Київ : Наукова думка, 1967. С. 6. 
little-known characters of local significance, domestic scenes, historical, heroic events of previous periods, still far from pre-Soviet times: "Thoughts about Bohdan Khmelnytskyi", historical songs about Danylo Nechai, Baida, Maksym Kryvonos, Morozenko, Zalizniak.

Researcher of Ukrainian Soviet folklore L. Yashchenko in his works gives examples of the emergence of a new musical product, which was created by transforming folk melodies and musical and poetic images. A large number of songs of that time were based on well-known examples of humorous folk songs, in particular the Kolomyia form. This tendency was traced in the song material of the Transcarpathian ethnographic region, exclusively in the genre of Kolomyia form. This is one of the traditional musical forms, in which the feature is the relative independence of melody and text, which allowed the poets-singers to cover the "necessary" plots, and the melody, in turn, served to spread them among the masses. Such traditional melodies became the typical basis and, so to speak, the most suitable material for new texts, which was the primary condition for the fulfilment of "new social orders" of the Soviet era.

For example:

All my Volyn sings,

Our destiny has come to life,

Glory to the Party, it is heard,

Praise the Constitution.

Thus, in 1963, a collection was arranged, which was published in a small edition of eight thousand copies in the series "Poet's Library". It presents Ukrainian-Soviet kolomyikas, which glorified the party, collective farms, the development of virgin lands and the "brotherly" Russian people. It should also be noted that the editorial board of that series officially included the luminaries of the Ukrainian literary word officially recognized by the then authorities - academician, poet and translator M. Rylsky, P. Tychyna, author of the anthem of Soviet Ukraine and editor-in-chief of the "Ukrainian Soviet Encyclopedia" - M. Bazhan, L. Pervomaiskyi and A. Malyshko. At the same time, in contrast to the propagandists, on the wave of a national upsurge in the 60 s of the twentieth century during the active development of the Ukrainian dissident movement: D. Pavlychko, P. Tychyna, V. Saussure, M. Rylsky made an invaluable contribution to the formation of Ukrainian authorship. Songs, some of their works set to music; the modern generation considers folk, for example, "Two Colours" by D. Pavlychko.

In contrast to the melodies of the Kolomyia form, lyrical songs of Dnieper Ukraine, which carry a rather complex harmonic palette: polyphonic texture, expansive melodic line, they are not the best example of this kind of 
modification in the lyrics ${ }^{5}$. Because the basis of this genre is a symbiotic combination of lyrics and melody, which carries the actual mood of the song, reveals its individual and holistic content. If we resort to radical changes in the text, through poetic intervention, the result is a negative perception in society, a dissonant sound of melody and text. A striking example of such a semantic modification is the novel "In a clear field". In the original, it is a lyrical song "Oh, from behind the mountain let the strong wind blow". The plotline has a deep meaning in life - reflections on the fate of a widow. The version, which was born in the process of text modification, on the matrix of the traditional melody - "In a clear field" - about a team of collective farmers and collective work. As a result of the complete replacement of the text part of the original song, there was a pronounced discrepancy between the text and the authentic character of the work.

For example:

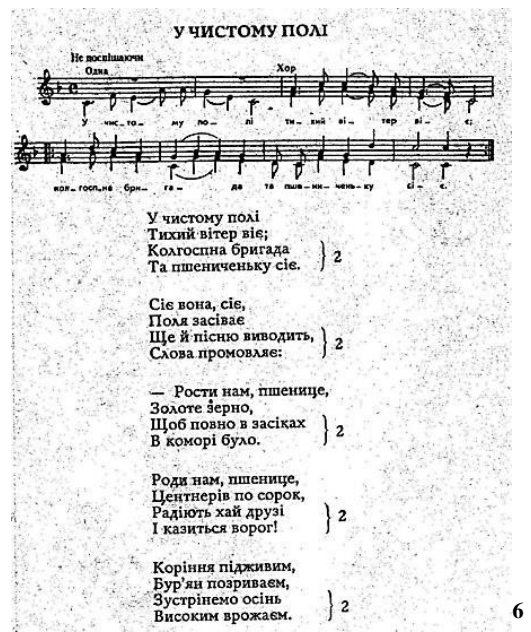

The newly created forms, which were the result of this kind of semantic modification, had no right to life at all, even so, to speak in the masses, in contrast to some author's songs that acquired a folk character, for example, "Two Colors" by D. Pavlychko.

It should be noted that in Soviet times, any traditional folk ritual, or lyrical song, was doomed to a gradual departure from widespread use and

5 Грица С. Необрядовий фольклор Західних регіонів України. Київ : Національний університет культури і мистецтв, 2020. 764 с.

${ }^{6}$ Ященко Л. Радянська пісня : монографія / за ред. А. Кінька. Київ : Наукова думка, 1967. С. 53. 
living tradition. First of all, this is clearly expressed in the artificial convergence of professional and folk art, which resulted in the phenomenon of stage folklore, which by the end of the twentieth century almost completely absorbed traditional culture in its authentic form ${ }^{6}$. There was a dynamic process of socio-cultural transformations, which resulted in structural changes in the rural environment, including the beliefs of the rural population. It is that we in call modern language as a "change of priorities".

In the 1930s, the time of "Ukrainization", poets-singers who benefited from the system appeared, whose work was based on direct interference in the cultural life of Ukrainians (D. Bedny and others). These are individuals who focused on the creation of relevant historical and social texts that covered the events of that period: such as the work of R. Rozhdestvensky "Ode to Lenin" (1976).

One of the means of spreading state ideology was the introduction of subjectivism into modified textual forms of traditional melodies. Among the publications of the poets-singers of that time, there were often cases of popular rejection, these were mainly "folk" creations related to the glorification of the cult of personality of J. Stalin. Such methods had clear propaganda content, and the introduction of subjectivism into folklore caused an appraisal of popular disgust. In the organic nature, the creators of poetic texts achieve the greatest success when the creative environment, in this case - the mass audience, can pick up their work and "analyze" its beauty and truthfulness. When a song is close in content to society, its performance arouses general interest and motivation for its improvement: the completion of images, music and lyrics. Because there is a hypothesis that art as a means affects a person directly in his specific, effective life situation, in its entirety, in the whole set of conditions of his social existence and higher spiritual manifestations (active being), forms personal beliefs, worldview ${ }^{7}$.

I. Berezovsky, Professor of Institute of Art Studies, Folklore and Ethnology named after M. Rylsky writes about the conditions of development of domestic folklore at that time in his monograph "Ukrainian Soviet folklore (stages of development and issues)". In his work, he reveals the main methods and forms of development of Ukrainian folklore of the Soviet period, based on the Marxism-Leninism ideological methodology.

The scientist notes that an important source of the rise of folklore work on a new methodological basis was the mass amateur art, which at that time was developing rapidly. Thus, with the assistance of the Ukrainian Central

\footnotetext{
7 Вороніна Г. Дослідження психологічного впливу мистецтва на особистість через структури самосвідомості (самоактуалізації) людини. Духовність особистості: методологія, теорія і практика. 2013. Вип. 1. С. 41-52.
} 
Committee of the Komsomol, in 1936 a festival of Ukrainian song, music and dance was held in support of the development of amateur art in Ukraine. In order to analyze and record the state of the traditional culture of Ukrainians, the organizers of the festival created a section of folklore collectors. And in September of the same year, the Council of People's Commissars of the USSR and the Central Committee of the CP(B)U adopted a resolution on the need for further development of amateur art in the then Ukrainian Republic at the state level. It should be noted that such a policy of the state was negative for the further functioning of traditional local cultures within the ethnocultural regions that have been formed over the centuries.

Thus, the intervention in the system of the traditional culture of Ukrainians had primarily a political and assimilative connotation and served as the beginning of the "standardization" of traditional regional cultures into a single system of propaganda of Soviet ideology with the help of mass culture. Since the adoption of the Council of People's Commissars of the USSR resolution, district, regional and republican amateur art competitions were systematically held, where various censored folklore materials were recorded and then published. Numerous review articles and informational reviews about these Olympiads noted the originality, first of all, of Soviet folklore, and set tasks to collect and study traditional and Soviet folk art.

\section{Transformation of traditional Ukrainian melodies in the context of the development of choral art in the conditions of socio-cultural changes}

The new wave of the rise of mass art was caused at that time by general attention to the song as a particularly influential factor in education, and the associated development of choral singing, as discussed in a special resolution of the People's Commissar of the USSR and the Central Committee of the $\mathrm{CP}(\mathrm{B})$ of Ukraine in 1936. At the same time, the first All-Union Choral Olympiad took place. It set the cult workers the task of intensifying the work of choral groups, to improve the culture of choral art. This was reflected in a number of performances by choral enthusiasts. In an editorial on August 15, 1939, the newspaper "Communist" emphasized the need to reorganize professional choral and musical ensembles to bring their work closer to the artistic practice of the masses ${ }^{8}$.

Ukrainian singing as a unique phenomenon in world culture in terms of scale, diversity and height of artistic level is represented by the work of leading conductors and choirs of Ukraine.

8 Березовський I. Українська радянська фольклористика: етапи розвитку і проблематика. Київ, 1968. С. 176. 
The precondition for the emergence of professional folk groups in Ukraine can be considered the creative practice of the Okhmativ folk choir under the direction of P. Demutskyi in the late nineteenth century.

"As a phenomenon that organically combined the authentic identity of folk group singing with the means of expression of academic music, the folk choral genre emerged in the late nineteenth century, crystallized and irrefutably proved its right to exist among other types of music of the twentieth century". This is what P. Andriichuk, an Honoured Cultural Worker of Ukraine, notes ${ }^{9}$.

Thus, in 1919, the first Volyn Soviet choir was created in Zhytomyr, led by M. Gaidai.

In 1920, the fame of Ukrainian song spread throughout the world thanks to the Ukrainian Republican Chapel under the direction of O. Koshyts. Also, the basis of professional choral performance was the State Honoured Academic Choir "Dumka", established in Kyiv in 1920.

Choral music in the 40s of the twentieth century became a leading branch of Soviet culture, which is characterized by social significance, censorship democracy, close ties with mass forms of music and artistic reflection of what was happening around and in society because the sphere of choral performance in this the period entered the world of amateur performing arts and attracted a wide contingent of people who had at least some abilities to music to create musical and artistic activities. There was an intensification of the mass choral movement, which spread throughout the country through the dedicated work of both professional musicians and amateurs ${ }^{10}$. In addition to the fact that choral music became a popular form of mass and public music, there was another reason for the mass development of choral creativity and performance during this period. Every year the number of choristers, deacons, regents, and composers deprived of work in the churches and monasteries closed by the Bolsheviks grew. They found work in numerous city chapels and choirs.

Fundamental practical activity in the formation of Ukrainian choral art was carried out by an outstanding conductor, teacher, and music and public figure, interpreter of Ukrainian traditional song Hryhoriy Veryovka. The versatility of his work has been repeatedly noted in the works of such figures of science and art as M. Hrynyshyn, A. Ivanytskyi, J. Klymenko, and S. Kozak.

A significant event in the formation of Ukrainian choral art of the twentieth century and to this day is the founding of the folk choir in Kharkiv

9 Андрійчук П. Актуальні проблеми керування народно-хоровим колективом. Вісник КНУКіМ: Мистецтввознавство. 2011. Вип. 5. С. 4.

${ }^{10}$ Там само. C. 4-8. 
in 1943 by Hryhoriy Veryovka, which now bears his name. A number of researchers of his artistic path evaluate H. Veryovka's activity and his creative work and the actual activities of the National Honored Academic Ukrainian Folk Choir, which is recorded in scientific articles, magazines, newspapers, in particular concerts of the choir abroad and in Ukraine. In particular, V. Dzhenkov in the article "Pride of Soviet Culture" points to the performance features of the State Ukrainian Choir, reveals the methods of $\mathrm{H}$. Veryovka's work with the choir, considers the work of this person as a talented conductor who formed a national style of singing ${ }^{11}$.

But still let's return to the regional traditional manners of singing, in contrast to V. Dzhenkov, the alternative is the opinion of the scientist A. Ivanytskyi, who notes in his work refutes the phrase "national manner of singing." In his conclusions, he is guided by the experience of the ensemble "Drevo" (leader E. Efremov) and the Kuban folk choir (leader V. Zakharchenko). A. Ivanytskyi states that: "No choir is able to master the regional specifics of the whole of Ukraine, where there are close (still unknown) 16-20 regional styles (Hutsul, Boikos, Lemkos, Galician - and not one, Bukovinian, Bessarabian, steppe, Polissian with varieties: western, central, eastern, Pokuttian, Podolsk style: eastern and western, Kubanian). In my opinion, the four styles demonstrated by the "Drevo" ensemble are the limit of mastery. This is possible also because the ensemble is small, so mobile $^{12}$. The active phase of Ukrainian professional music development dates back to the 60s and 70s and is characterized by the improvement of all its genres, the creation of new operas, ballets, symphonies and songs. Special achievements can be traced in mass songwriting. Popular at that time were the songs "Dew fell on the mow" by D. Pavlychko, "Marichka" by M. Tkach, "Chornobryvtsi" by M. Sinhaivskyi, melodies by P. Maiboroda, O. Bilash, I. Shamo. Characteristic features of this period were a certain departure from the brutal total Stalinist system, reforms in the direction of liberalization, relative democratization, and humanization of political and social life.

Already in the $60 \mathrm{~s}$ of the last century, all spheres of Ukrainian culture felt the beneficial effect of the "thaw". Especially this period gave impetus to the development of amateur art, at this time the number of groups reached 200 thousand, and the number of participants exceeded 3.5 million people.

In conclusion, it should be noted that the Soviet stage is marked in the cultural life of Ukraine by sharp contradictions and tragic events. Our culture has suffered huge losses; hundreds of talented masters have died. Authorities imposed a heavy pressure on scientific thought, primitive it, in the field of literature and art, there was a decrease in the aesthetic level. Under the false

11 Іваницький А. Історичний синтаксис фольклору. Проблеми походження, хронологізації та декодування народної музики. Вінниця : НОВА КНИГА, 2009. 404 с.

${ }^{12}$ Іваницький А. Про хор Г. Верьовки і не лише. Київ : Музика, 1993. № 3. С. 10. 
slogans of the "new historical community" and "the only all-Soviet international culture", the processes of denationalization of the Ukrainian people intensified. However, all this failed to put the Ukrainian intelligentsia in a position of contemplative, conciliatory nature. The best part of it fought for democratic rights and freedoms, including freedom of creativity, for favorable conditions for the development of national culture. At the same time, some poets-singers actively praised the new progressive phenomena of the Soviet reality, the heroic themes of the Civil and Patriotic Wars - all this was then considered the basis for innovation in art, including collective one.

In the conditions of totalitarianism of the twentieth century in Ukraine, there was still a full-scale struggle for national and social liberation of the people. The national elite gave impetus to the development of choral performance, in the context of new cultural demands of society. At this time, choral art has acquired those signs of significance that until recently could not be imagined. On the one hand, a long process of choral song revival began, in the context of stage performance, in the arrangements of such composers as M. Leontovych, L. Revutskyi, M. Lysenko, K. Stetsenko and others. But on the other hand, new arrangements of folk songs and their musical fixation served as a direct factor in the transformation of stylistic varieties of traditional musical works of different ethnocultural regions of Ukraine, to which the whole work "Ukrainian folk music" by A. I. Ivanytskyi is dedicated. Through the state media, this "product" is rapidly spreading among the masses. Thus, the song "Tyman Yarom" ("Fog in Gorge") was already known and sung throughout the geographical territory of Ukraine, regardless of ethnocultural zoning. In the conditions of development of choral art, the mechanism of erosion of Melo-geographical zoning and merging of stylistic varieties of traditional folk singing together was started.

It should be noted that under the influence of socio-political factors, works of the author's origin of the Soviet period, including those that are subtextual to the melodic matrix of ritual songs, performed a propaganda function. As for the traditional performance of songs in everyday life, or ritual actions, they have been modified, and even, in some cases, the rites ceased to exist as a living functional natural-traditional component in the customary-ritual system. Given the primary syncretic multifunctionality of folk art (communicative, utilitarian, aesthetic and others), we mean exclusively authentic folklore, which reflects the genesis of the Ukrainian people in the period from the 30 s of the twentieth century and to date, a pronounced tendency towards simplification and mono functionality - the satisfaction of purely aesthetic needs. But in Ukraine, in conditions of totalitarianism, discrimination of the nation, which was on the verge of physical destruction, since the time of poets-singers of the Soviet system and contemporaries, there has always been and still is the phenomenon of folklore with the preservation of traditional regional cultures. To determine 
the approximation of folklore to tradition in the modern circulation of scientific terminology introduced the concept of "secondary", "tertiary", and even "Quaternary folklore". They characterize the closeness of the activities of professional groups, or rather, their stage representation of musical folklore in accordance with the regional manners of traditional authentic performance. Along with this, the tendency of the author's interpretation has become widespread nowadays: the combination of folklore with other genres of musical art. This trend has the right to live in today's world because it meets demand and the aesthetic needs of society in the 20th century. But the most important thing is not to lose the eternal code of the nation in the conditions of global transformations of the present, which has been formed during the millennial history.

Ukrainian traditional art at the turn of the $20^{\text {th }}-21^{\text {st }}$ century, as well as Western European, is characterized by a tendency to unite and interpenetrate different phenomena within the traditional national culture. A striking example and driving force of what we call "destructive changes in folk art" is the active movement of amateur art in the $40 \mathrm{~s}-60 \mathrm{~s}$ of last century. Already at the end of the twentieth century, there is a synthesis of the folk tradition with pop music, which created new imagery and means of musical expression in accordance with the requirements of the time.

If we talk about traditional music culture, then, on the one hand, it developed within the general trends that were present in the domestic space. In particular, with the change of socio-cultural conditions at the beginning of the 20th century there was a gradual decline of folklore. With the development of the policy of the Soviet government, the only possible form of broadcasting folklore was the activities of folk groups that could perform traditional musical material. At the same time, a number of figures contributed to the development of the region's cultural heritage by composing songs in various collections. Thus, there was a certain "conservation" of folklore in order to preserve and the possibility of further translation. These factors contributed to the formation of cultural heritage, which could be reproduced, although it did not contain information about the peculiarities of the musical component ${ }^{13}$.

Folk art culture in the chronotope of socialist realism was completely under the control of the state. The Soviet government constantly resorted to influencing mass consciousness through cultural socio-psychological mechanisms. Folklore was actively used by power structures, and the change of the state system and

13 Овчаренко С. Традиційна музична культура Чернігівщини в контексті соціокультурної динаміки XX - XXI століття. Вісник РДГУ: Укр. культура: минуле, сучасне, шляхи розвитку (наприклад, мистецтвознавство). 2020. № 34. С. 261-265.

URL: http://ucpm.rv.ua/index.php/ucpmk/article/view/352/320 (дата звернення: 17.01.2020).

DOI: https://doi.org/10.35619/ucpmk.v34i34.352. 
socio-cultural system clearly caused a change of folklore traditions. Leading politicians, as well as cultural and artistic figures, based on traditions, added new nuances to them, creating new customs and traditions, based on ideologically acceptable events for the then state system, formed their own system of traditions. Understanding the internal structure, dynamics, patterns of development and identification of the functions of Soviet rituals, which according to the laws of socio-cultural succession of traditions in the chronotope of Soviet culture has become a qualitatively new phenomenon, suggests that the formation of folk-art traditions was due to changing socio-economic formations and sociocultural systems. The emergence of new traditions, as a rule, reflected the events that characterized the fundamental target guidelines of a particular socio-political system, while folk traditional ritual forms of folklore played the role of a deterrent, a kind of "brake" for rooting new traditions.

On the basis of the analyzed materials, it is possible to allocate some stages of transformation of folklore:

- folklore (in an authentic form);

- folklore (folk art in the interpretation of secondary folk groups);

- folklorization.

Folklorization - musical works created with elements of traditional music-making, by introducing melodic, verbal, melodic-verbal destruction of original (authentic) patterns that played an ideological role at a certain historical stage of socio-political development of society.

Folklorization is most vividly reflected in the pop art of the $21^{\text {st }}$ century, due to the need for accessible forms of music in modern youth. This can be traced to the example of modern pop-folk groups, such as - "THE DOOX", "FOLKY-FANKY", "YOU-KO", which successfully combine folk traditions with pop, pop-jazz, pop-rock music ${ }^{14}$. It is also safe to say that modern popular music has acquired a different color thanks to these techniques. It was supplemented by new means of expression, sound production techniques, the instrumental composition was expanded, which includes traditional aerophone instruments, such as tylynka, sopilka, nai. Folklore continues to live thanks to the means of author's interpretation and acquire new rhythmic forms and melodic structures, a new modern style of vocalization and the use of electronic instruments, which gave it a new modern sound and color.

${ }^{14}$ Овчаренко С. Зміни в традиційному пісенному виконавстві в процесі переходу від автентичного фольклору до фольклоризму. Імідж сучасного педагога. 2020. № 3 (192). C. 81-84. URL: http://isp.poippo.pl.ua/article/view/205908/pdf 58 (дата звернення: 28.12.2020). DOI: https://doi.org/10.33272/2522-9729-2020-3-81-84. 


\section{CONCLUSIONS}

A study of modern Ukrainian traditional performance suggests that the system of customs, traditions, and, in particular, traditional melodies give a broad idea of the moral, ethical, aesthetic views of the people. It is the traditional melodies, in the modern secondary interpretation, that perform important social and educational functions: first of all, it is the formation of awareness and self-awareness as a Ukrainian.

Taking into account the opinions of leading researchers of folk art of the twentieth century (S. Hrytsa, O. Pravdiuk, L. Yashchenko) and based on their own intelligence, it was found that under the influence of sociopolitical factors: urbanization, industrialization, elimination of illiteracy in the20s-the 30s of the twentieth century. During the Soviet period, traditional Ukrainian melodies underwent significant modifications.

The comparative analysis of the traditional song material of the Transcarpathian and Dnieper ethnocultural region revealed that the most suitable matrix traditional melodies for the newly created plots are songs of the Kolomyia form. It was clarified that one of the ways of change was the complete semantic replacement of traditional texts (subtext) in many ethnocultural regions, which carried a transformational meaning into the local traditional context. Thus, it served for spreading of a new song product throughout Ukraine. This led to the blurring of Melo-geographical boundaries of ethnocultural zoning and contributed to the beginning of the formation of a national style of singing.

It was found that the cause of the phenomenon of semantic modification in the period 1917-1991 was the state ideological system of persecution of Ukrainian traditional melodies, ritual actions in their widespread use, and soon.

The tendency to use music as a tool for planting Soviet ideology is observed that is a distribution to the masses of a musical product with to some extent modified plots, or in general, subdued by new plots on an authentic melodic matrix of traditional Ukrainian melodies, carried out with the help of the then media, in order to spread the propaganda state ideology.

It was found that the semantic modification, through experiment, affected all song genres of folk art.

It should be noted that the active movement of choral amateur art synthesizes folk traditional music with the author's, which carries new imagery and means of musical expression, but has a negative impact on the authentic performing culture of all regions of Ukraine.

In the conditions of totalitarianism of the twentieth century in Ukraine, there was still a full-scale struggle for national and social liberation of the people. The national elite gave impetus to the development of choral performance, in the context of new cultural demands of society. At this time, 
professional choral art has acquired those signs of significance that until recently could not be imagined.

However, it is worth emphasizing the political oppression of the researchers' scientific opinion of traditional Ukrainian music during Soviet Ukraine. The main task today is to eliminate ideological layers in the assessment of scientific achievements of collectors of Ukrainian musical folklore of the twentieth century.

In modern realities, a comprehensive study of traditional culture is necessary to solve many theoretical and practical problems of today, because the involvement of elements of folklore in all areas of modern music culture is seen. Musical folklore is one of the most stable and complex components of traditional household and spiritual culture - an indicator of ethnic identity.

\section{SUMMARY}

Folklore is an important source for studying the life and way of life of the indigenous population, in particular the regional song traditions of Ukraine, which functioned as an organic connection of spiritual and material in the process of the people existence. The article analyzes the processes that caused the semantic modification of the traditional Ukrainian melodies' texts and contributed to the transformation of the ritual system.

The aim is to specify the facts of the influence on the authentic song tradition during the Soviet period (1917-1991), which led to the modification of symbiotic local regional melodies (on the example of song material of Dnieper Ukraine and Transcarpathia).

The research used such methods as historical-comparative (to clarify the chronological sequence of influences on traditional performance), comparative (to determine the Melo-geographical features of making music depending on the ethnocultural region), descriptive (to consider the formation and development of professional and amateur choral art in Ukraine).

The scientific novelty of the study is to prove the facts of modification of the musical folklore organic functionality in the specified period of time and affirmation of previously discovered facts of subtexting author's poems to traditional melodies, functionally unsuitable for low-quality newly created plots, which resulted in a semantic modification of regional traditional Ukrainian songs of the Dnieper and Transcarpathian ethnocultural regions.

Conclusions: Taking into account the opinions of leading researchers of folk art of the twentieth century (S. Hrytsa, O. Pravdiuk, and L. Yashchenko) and based on author's own findings, it has been found that under the influence of socio-political factors, during the Soviet period, traditional Ukrainian melodies underwent significant semantic modification. 
It has been specified that one of the ways of these changes was the complete semantic replacement of traditional texts (subtexting) in many ethnocultural regions, which carried a transformational meaning into the local traditional context. This led to the blurring of the Melo-geographical boundaries of ethnocultural zoning of Ukraine and contributed to the formation of a national choral style of singing.

\section{REFERENCES}

1. Андрійчук П. Актуальні проблеми керування народно-хоровим колективом. Вісник КНУКіМ: Мистеитвознавство. 2011. Вип. 5. С. 4-8.

2. Брайченко O. Побутування українських традиційних свят родинного циклу в умовах наступу радянської ідеології 70-80-х років ХХ століття. Народна творчість та етнологія. 2014. № 4. С. 115-127.

3. Березовський I. Українська радянська фольклористика: етапи розвитку і проблематика. Київ, 1968. $341 \mathrm{c.}$

4. Вороніна Г. Дослідження психологічного впливу мистецтва на особистість через структури самосвідомості (самоактуалізації) людини. Духовність особистості: методологія, теорія і практика. 2013. Вип. 1. С. 41-52.

5. Грица С. Фольклор і сучасність. Украӥнська художня культура : навчальний посібник. Київ, 1996. С. 300-314.

6. Грица С. Необрядовий фольклор Західних регіонів України. Київ : Національний університет культури і мистецтв, 2020. 764 с.

7. Іваницький А. Історичний синтаксис фольклору. Проблеми походження, хронологізації та декодування народної музики. Вінниця : НОВА КНИГА, 2009. 404 с.

8. Іваницький А. Про хор Г. Верьовки і не лише. Музика. 1993. № 3. С. $10-15$.

9. Овчаренко С. Традиційна музична культура Чернігівщини в контексті соціокультурної динаміки XX - XXI століття. Вісник РДГУ: Украӥнська культура: минуле, сучасне, шляхи розвитку (наприклад, мистеитвознавство). 2020. № 34. С. 261-265. URL: http:/ucpm.rv.ua/index.php/ucpmk/article/view/352/320 (дата звернення: 17.01.2020). DOI: https://doi.org/10.35619/ucpmk.v34i34.352.

10. Овчаренко С. Зміни в традиційному пісенному виконавстві в процесі переходу від автентичного фольклору до фольклоризму. Імідж сучасного педагога. 2020. № 3 (192). С. 81-84. URL: http://isp.poippo.pl.ua/article/view/205908/pdf_58 (дата звернення: 28.12.2020). DOI: https://doi.org/10.33272/2522-9729-2020-3-81-84.

11. Потебня А. Объяснение молорусских и сродных народных песен. Варшава, 1883. Т. 1. 
12. Садовенко С. Обрядовість у хронотопі радянської культури: від традиційних до новітніх утворень. Вісник НАККіМ: Культурологія. 2017. № 4. С. 76-83.

13. Ященко Л. Радянська пісня : монографія / за ред. А. Кінька. Київ : Наукова думка, 1967. 376 с.

\section{Information about the author:}

Ovcharenko S. V.,

Assistant at the Department of Music

Kyiv National University of Culture and Arts

36, Ye. Konovalets str., Kyiv, Ukraine 